\title{
Hadımların Pers Saray Yaşamındaki Yeri
}

\author{
Serap Özkan Kılıça,b
}

\section{Özet}

Hadımların Pers saray yaşamındaki yeri ve üstlenmiş olduğu rollerini ortaya koymaya çalıştığımız araştırmamızda, öncelikli olarak Antik Hellen ve Roma kaynaklarının verdiği bilgilerden yararlanılmıştır. Hadımlara dair bilgilere Ön Asya, Anadolu ve Uzak Doğu'daki pek çok uygarlıkta rastlanmasına rağmen, en erken yazılı belgeler Çin Shang ve Ming hanedanlıklarında ortaya çıkmıştır. Perslerde hadım etme eylemi, başlangıçta bir cezalandırma yöntemi olarak kullanılsa da sonrasında hadımların Pers sarayında edindikleri olumlu-olumsuz rolleri Herodotos, Diodoros, Ksenophon, Ktesias, Plutarkhos ve Platon gibi kaynaklar aracılığıyla izleyebiliyoruz. Yakın Doğu saray yaşamının izlerini gördüğümüz Persler, aslında öncesinde alışık oldukları geleneksel Med saray anlayışının birçok özelliğini de taşımaktadır. Hadımların, Pers saray yaşamında kral ve ailesinin yakınında yer alan kişiler olduğu açıktır. Antik kaynakların verdiği bilgiler de bu konuda paralellik göstermektedir. Özel yaşam, hizmetçilik ve eğitim olarak sınıflandırdı ğımız başlıklar altında hadımların Pers saray yaşamındaki rollerini detaylı olarak incelediğimizde, hizmetçilik dahil olmak üzere önemli görevler üstlenen karakterler olduğunu görmekteyiz. Sarayın gizli bilgilerine hakim, haremde olan bitenden haberdar, üstüne üstlük haremdeki yaşamın gizliliği ve düzeninden sorumlu olan hadımlar, Pers İmparatorluğu'nun güçlü olduğu dönemlerde sadakatleriyle öne çıkarken, imparatorluğun çöküş süreciyle birlikte daha olumsuz karakterlere dönüşmüştür.
Anahtar Kelimeler

Hadim

Saray Yaşamı

Harem

Eğitim

\section{Makale Hakkında}

Geliş Tarihi: 09.04.2020

Kabul Tarihi: 24.04.2020

Doi: 10.18026/cbayarsos.717382

\section{The Eunuchs in the Persian Palace}

\begin{abstract}
We aim to reveal the place and roles of castrated people in Persian palace life within scope of current research based on the information primarily given by the sources of Ancient Greek and Rome. Although information on eunuchs may be provided by many civilizations in Asia Minor, Asia and the Far East, the earliest written documents appeared in the Shang and Ming dynasties in China. Although the act of castration in the Persians was originally used as a method of punishment, we can follow the positivenegative roles of the castrated in the Persian palace through sources not limited with Herodotos, Diodoros, Xenophon, Ktesias, Plutarch and Plato. The Persians, on which we see the traces of the Near East palace life, actually bear a large number of properties of the traditional Med palace approach and conventions familiar to them. It is clear that the eunuchs are the people who are closest to the king and his family in Persian palace life which is overwhelmingly supported by evidence provided in ancient resources. Detaile inspection of the roles of castrated people in Persian palace life under the titles we classified as private life, servantism and education reveals characters with important duties including service. The eunuchs, who are aware of the secret information of the palace, had a command of what is happening in the harem and were responsible for the privacy and order of the life in the harem, were initially loyal figures in bright days of empire, later turning into more negative characters with the collapse of the empire.
\end{abstract}

Keywords

Eunuch

Palace Life

Harem

Education

About Article

Received: 09.04.2020

Accepted: 24.04.2020

Doi: 10.18026/cbayarsos.717382 


\section{Giriş}

Hadım etme eylemi ve hadımlar tarih boyunca pek çok toplumda karşımıza çıkmaktadır. Özellikle Uzak ve Yakın Doğu'da kurulan imparatorlukların (Çin, Mezopotamya, Mısır, Anadolu/Geç Hitit, Pers ve Bizans) çoğunda hadımlar saray yaşamında, yönetimde ve orduda çeşitli pozisyonlarda yer almışlardır. Sınırlarını İndus Vadisi'nden Kuzey Hellas'a, Orta Asya'dan Güney Mısır'a dek genişleten ve antik dünyanın en önemli güçlerinden biri olmayı başaran Pers İmparatorluğu'nda hadımların sosyal yaşam içerisindeki yerini incelemeden önce, hadım kavramına hem tıbbi hem de tarihsel açıdan kısaca bakmak gerekir.

Hadım kelimesi halk arasındaki en basit tanımıyla "kısırlaştırılmış erkek" anlamına gelmektedir. Ancak Tıp biliminde kısırlaştırma, bir hadım etme işlemi değildir. Her iki cins için (kadın/erkek) yumurtalık veya testislerin çıkarılarak testosteron ve östrojen adlı hormonların salgısını durdurma işlemine hadım etme veya kastrasyon adı verilmektedir. Hadım etmede bireyin cinsel arzularını harekete geçiren dürtüler ortadan kaldırılırken, kısırlaştırmada ise cinsel dürtüler ortadan kaldırılmaksızın üreme yeteneği sona erdirilmektedir (Sarp, 2013: 51).

Hadımların ilk ortaya çıkışı ile ilgili kesin bir bilgi bulunmamasına rağmen, Taylor insanları hadım etme eyleminin kökenini İÖ 4000'lere dayandırmakta ve Mezopotamya'daki Sümer kültürünün en büyük kentlerinden biri olan Uruk'taki İşhtar/İnanna kültüyle ilişkilendirmektedir (2000: 169). Öte yandan ilkçă̆ tarih yazımının önemli yazarlarından biri olan Hellanikos ise hadım edilen kölelerin kullanılmasını Atossa'ya atfetmektedir (FgrH 687 F. 7; FgrHF. 178; Gera, 1997: 141, 146-148). Hadım kavramını kesin olarak sunan belgelerde; en erken Çin Shang Hanedanlığı'nda (İÖ 1766-1122) imparatorun hizmetkarları olarak görev yapan hadımların varlığı bilinmekte, sonrasında Ming Hanedanlık (İS 14-17) döneminde ise bunların zamanla rollerini büyükelçilik, diplomatlık veya komutanlığa kadar yükselttikleri anlaşılmaktadır (Scholz, 2001: 22; Tougher, 2008: 7)

Tarihsel sürece bakıldığında, pek çok toplum tarafından insanların en çok cezalandırma amacıyla veya savaşlarda esir düşme sonucunda kasıtlı olarak hadım edildikleri görülmektedir. Savaşlarda esir düşenlerin bir kısmı hadım edilerek Sardeis ve Ephesos gibi dönemin ünlü köle pazarlarında satışa sunulmaktaydı (Herodotos. III. 48, VIII. 105). Herodotos'a göre Persler de bu cezalandırma yöntemine başvurmuşlardır. İÖ 499 yılında Pers boyunduruğuna karşı başlatılan Ionia İsyanı'na katılan kentlerin tyranlarına Persler şu uyarıda bulunmuşlardır:

"...Ioniahılar, işte sizin için krala yararlı olmanın zamanı geldi; karşı yandaki yurttaşlarınızı kazanmaya çalışınız; onlara şöyle söz veriniz: Ayaklandıkları için ceza görmeyecekler, ne tapınakları ne de mülkleri yakılacak, eskisinden daha ağır bir muameleye uğramayacaklar. Ama sizi dinlemezler, ne olursa olsun deyip savaşa girerlerse başlarına nelerin geleceğini de iyice anlatını: Savaşı kaybedecekler ve köle olacaklardır; oğulları hadım edilecek, kızları Baktra'ya gönderilecek, toprakları başkalarına verilecektir." (Herodotos. VI. 9)

Perslerin bu söyleminin bir tehdit olarak kalmadığını yine Herodotos aracılığıyla öğreniyoruz:

"Pers şefleri, gemileriyle gelip Ionia gemileri karşısına dizildikleri zaman Ionialılara karşı savurdukları tehditlerin hepsini gerçekleştirmişlerdir. Bir siteye girdikleri zaman en güzel oğlan çocuklarn ve çocuk yapabilecek erkekleri hadım edilmek üzere ayırıyorlardı; en güzel kızlar Büyük Kral'ın sarayına gidiyorlardı. Aynı anda kentleri ve tapınakları ateşe veriyorlardı..." (Herodotos. VI. 32). 
Herodotos, Pers kralı I. Dareios'un Pers satraplık listesi arasında saydığı dokuzuncu satraplığ

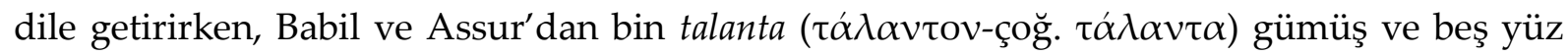
iğdiş edilmiş oğlan çocuk vergi alacağından söz etmektedir (Herodotos. III. 92; Briant 1996: 284). I. Dareios'un tahta geçtiği dönem düşünülürse, bu talebin böylesi bir karışıklık ortamında Babil ve Assur üzerinde bir baskı unsuru olarak kullanıldığını varsayabiliriz.

Bununla birlikte, Herodotos ve Ksenophon hadım kölelerin daha güvenilir ve sadık olduklarını da sıklıkla vurgulanmaktadır (Herodotos. I, 117, VIII. 105; Xenophon. Cyr. VI. 1. 33-34, VI. 4. 11, VII. 3. 5, VII. 3. 15, VII. 5. 58-65). Pers saray yaşamında hadımların geniş bir yer bulması, aslında onlara duyulan güveni de yansitıyor olmalıdır.

\section{Kaynaklar ve Terminolojik Problemler}

Hadımların Pers saray yaşamındaki yerini öncelikli olarak Herodotos, Ksenophon, Ktesias, Sicilyalı Diodoros gibi antik Hellen yazarlarının yanı sıra, Roma döneminin en önemli tanıklarından biri olan Plutarkhos aracılığıyla öğrenmekteyiz. Pers hadımları hakkındaki bilgilerimiz ağırlıklı olarak antik Hellen kaynaklarına dayandığından, hadım sözcügünün karşılığını yine bu kaynaklarda kullanılan farklı terimler üzerinden tartışabiliyoruz (Kuhrt, 2007; Llewellyn-Jones, 2002: 19-50). Tougher, hadım sözcügünün Eski Hellence thladias $(\theta \lambda \alpha ́ \delta \iota \alpha \varsigma)$, yani ezmek, çürütmek anlamina gelen thlao $(\theta \lambda \alpha \dot{\omega} \omega)$ fiilinden geldiğini ve penisi sağlam birakarak testisleri ezmek gibi bir yöntemin söz konusu olduğunu ifade etmektedir (2008: 30).

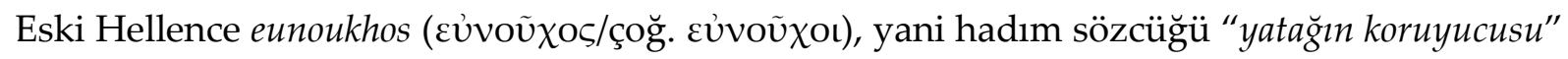

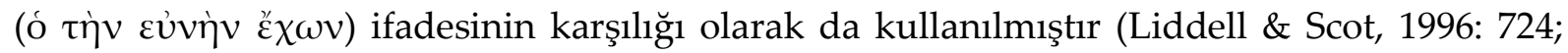
Herodotos. III. 92, VIII. 105; Xenophon. Cyr. VII. 5. 59; Briant, 2002: 276; Tougher, 2008: 8, 22; Ringrose, 2003: 16; Waters, 2017: 24). Sonrasında, bu kavram Roma İmparatorluğu'ndan Bizans'a kadar süregelmiş ve günümüz batı dillerine eunuch sözcüğü olarak yerleşmiştir. Hellen kaynaklarının yanı sıra Pers kraliyet yazıtları ve Persepolis arşivinde bulunan kil tabletlerde saray yaşamı, kadınlar ve kısıtlı da olsa hadımlar hakkında bilgi edinmek mümkündür (Brosius, 1996: 123 vd.).

Ktesias, Persica (Persika) adlı eserinde hadımları Pers siyasi yaşamındaki çeşitli ayaklanmalar, krallarının tahta çıkması-indirilmesi, hatta kral ölümleri vb. olaylarla ilişkilendirmiştir. Ksenophon Kyrou Paideia'da (Kyros'un Eğitimi) hadım Gadatas'ı hem II. Kyros'un yakın destekçisi hem de II. Kyros'un düşmanı Babil Kralını öldüren bir kral katili olarak aktarmaktadır (FgrH F. 1, FgrH F. 90; Xenophon. Cyr. VI. 1. 1). Herodotos da Pers kralı II. Kambyses Mısır'dayken tahtı gasp eden ve Kambyses'in ölümüyle krallığını ilan eden rahip

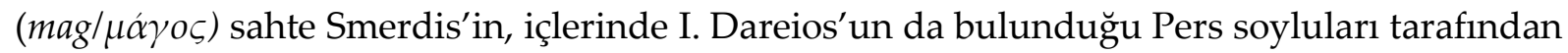
öldürülmesini aktardığı pasajında, kapıyı koruyan hadımların (harem ağaları) baskına göz yumduklarını ima ederek, benzer bir olumsuz yaklaşım sergilemektedir (Herodotos. III. 77). Fakat, aynı antik kaynaklar hadımların güvenilirliğinden, sadakatinden hatta sarayın kapılarını koruyacak kadar güven duyulan insanlar olduğundan da söz etmektedir. Hadımlara dair mevcut Pers kaynaklarının kısıtlı olması, yapılan çalışmaları daha çok antik Hellen kaynaklarının verdiği bilgilere dayandırmaktadır (Llewellyn-Jones, 2002: 22). 


\section{Hadımların Görevlendirildiği Alanlar}

\section{Özel Yaşam (Harem)}

Harem sözcüğü Arapça "yasak, kutsal şey" anlamına gelen haram kelimesinden türemiştir (Llewellyn-Jones, 2013: 97). Başka bir deyişle, harem sözcügünü "evin (yaşam alanının) kadınlara-çocuklara ayrılan bölümü" olarak tanımlamak da mümkündür.

Briant'a göre Pers hadımlarının saraydaki asıl görevi, kralın hareminde bulunan kadınları korumaktır (2002: 273; Llewellyn-Jones, 2002: 21). Aslında haremdeki kadınların tek cinsel partnerinin Pers kralı olması gereğinden dolayı hadımlar bu iş için idealdi. Çünkü haremdeki kadınlardan doğan her çocuk Pers kralının soyundan kabul ediliyordu. Hadımlar, harem hayatının düzen ve işleyişinde yer aldığı kadar korunmasında da görev almış olmalıdır. Ksenophon'a göre, hadımlar fiziksel açıdan erkekler kadar güçlü olmasa da silah (çelik) kullanımı, bir çarpışmada zayıfla güçlüyü eşit hale getirmektedir (Xenophon. Cyr. VII. 5. 65).

Herodotos, Ksenophon ve Ktesias gibi antik yazarların ilgili bölümleri incelendiğinde, hadımların tahta çıkma olasılı̆̆ı bulunan varislerin ortadan kaldırılmasının yanında çeşitli politik karışıklıklar, intikam ve şiddet gibi olumsuz davranışlarla ilişkilendirildiği dikkat çekmektedir (Herodotos. I. 113-117, III. 77, VIII. 104-106; Xenophon. Cyr. VI. 1. 1; FgrH F. 1, FgrH F. 90). Olumsuz bazı örneklerle anılsalar da saraydaki özel yaşamın korunması ve haremdeki kadınların Pers kralına sunulması gibi görevleri güvenli bir şekilde sürdürebilecek kişiler olmaları, hadımları saray yaşamında bir adım öne çıkarmaktadır. Pers sarayında hadımlar krala aittir ve saray içerisinde neler olup bittiğini en iyi bilen kimselerdir. Dolayısıyla, hadımlar aynı zamanda krala erişme yolarından biri olarak görülmüş olmalıdır. Pers tahtını ilgilendiren birtakım sorunlarda hadımların rol oynaması bu açıdan değerlendirilmelidir

Sicilyalı Diodoros, seferler vb. yolculuklara Pers krallarının eş ve çocukları ile birlikte çıktıklarını ve bunun bir Pers geleneği olduğunu dile getirir (Diodorus Siculus. XVII. 35. 3). Kraliyet ailesinin günlük yaşamdaki konforunun sürmesi, hizmetçilerin de bu yolculuğa eşlik etmesini gerektirir. Harem yaşamının önemli parçası olan hadımlar, bu tür seyahatlerde kral ve ailesine hizmet etmeye devam etmiş olmalıdır. Herodotos, I. Kserkses'in Hellas üzerine düzenlediği sefer sırasında, karısı Artemisia ve (gayri meşru) çocuklarının yanında bulunduğunu benzer şekilde doğrulamaktadır (Herodotos. VIII. 103-104). Pers krallarının bazı gezi ve seferlere ailelerinin yanısıra yakın koruma askerleri eşliğinde çıtıkları bilinmektedir (Wiesehöfer, 2003: 68-72).

\section{Krala Yakın Hizmetler (Hizmetçilik)}

Antik Hellen kaynaklarında "saki/şarap-içki servis eden, kap taşıyıcısı" olarak tanımlanabilecek,

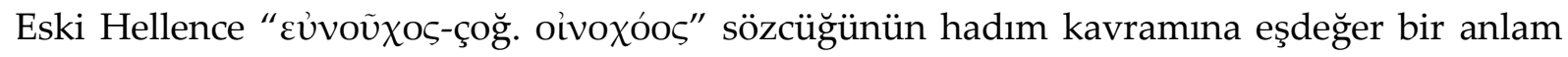
yüklenerek kullanılması karışıklığa neden olmaktadır (FgrH 90 F. 90; Gera, 1993: 159). Briant,

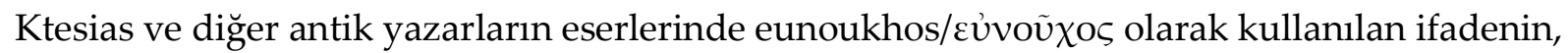
Akadca "ša rēš šarri”, "kralın başındalyanında bulunan kişi” anlamından yola çıkarak hadımların Pers kralının yakınındakiler ya da danışmanları olduğunu önermektedir (2002: 273). Saray yaşamının özel ve kritik noktalarında görev almaları göz önünde bulundurulduğunda, hadımlar kral ve saray yaşamına oldukça yakın karakterler olmalıdır.

Ksenophon, Kyrou Paideia'da II. Kyros'un dedesi Astyages ile yapmış olduğu bir sohbeti aktarırken, Med krallarına şarap sunan hizmetçilerin/sakilerin şarabı sunmadan önce kepçeyi 
kaba daldırıp elinin oyuğuna biraz dökerek yudumladığından, böylece şarapta zehir olup olmadığının anlaşıldığından söz eder (Xenophon. Cyr. I. 3. 9). Kralın zehirlenme ihtimaline karşı alınan önlemde görev yapan hizmetçilerin de güvenilir kişiler olması gerekmektedir. Buradan yola çıkarak, hadımlara kralın hayatını emanet edecek kadar güven duyulduğu veya kralın yakınındaki kimseler olduğu düşüncesi akla yakın görünmektedir. Medlerden sonra soy ve kabile açısından devamı olarak nitelendirilebileceğimiz Perslerin, Medlerden devralıp kurdukları imparatorlukta sürdürdükleri saray yaşamında karşılaştığımız benzerlikler de tesadüfi değildir. Giyim kuşamdan çocuk eğitimine Med saray yaşamında görülen birtakım gelenekler Pers sarayında yaşamaya devam etmiştir.

Yakın Doğu'daki birçok toplumda, hadımlar genellikle sarayda hizmetçilikle görevlendirilmiştir. Bu yönüyle ele aldığımızda hadımların saray yaşamında daha düşük bir statüye sahip olduklarını düşünmek de mümkündür (Gera, 1993: 159). Ancak, Antik Hellen kaynaklarında karşılaştığımız ve yukarıda sözünü ettiğimiz terminolojik belirsizlikler yüzünden, Pers sarayının çeşitli kademelerindeki hadımların hiyerarşik konumu veya bulundukları konumda ne kadar etkin olduklarını anlamak güçleşmektedir.

Ksenophon'un aktarımına göre, Pers kralı II. Kyros'un destekçilerinden Abradatas'ın savaşta ölmesi üzerine, karısı Panthea kocasının ölümüne dayanamayarak canına kıymış ve Panthea'nın hadım hizmetçileri de efendilerinin ölümüne dayanamayarak oracıkta intihar etmiştir (Xenophon. Cyr. IV. 6. 11, V. 1. 2-18, VI. 1. 31-51, VI. 3. 14-21, VI. 4. 2-11, VII. 1. 15-18, VII. 1. 29-32, VII. 3. 2-16). Ksenophon, Panthea öyküsünün dışında da sıklıkla hadımların sadık hizmetkarlar olduğundan, efendilerinin ölümünden sonra bile onlara sadık kalmalarından ve diğer erkeklerden fiziksel olarak zayıf olmalarına rağmen cesaretlerinin hiç de az olmadığından söz eder (Xenophon. Cyr. VI. 1. 33-34, VI. 4. 11, VII. 3. 5, VII. 3. 15, VII. 5. 58-65).

Herodotos, hadım edilmeyi iğrenç bir eylem olarak aktarırken aynı zamanda Eski Hellen toplumunun konuya bakış açısını da yansıtmaktadır (Herodotos. VIII. 105-106; Gera, 1993: 288). Hadımlar aile bağları olmadığı için her şeyden önce efendilerini sevmeye ve bağlanmaya daha yatkın olmalıdır (Azoulay, 2000: 17; Gera, 1993: 288). Özellikle de hadımların köle pazarlarında satılmaları onları kötü muameleye açık hale getirmektedir. Bu yüzden kendilerine iyi davranan ve koruma sağlayan efendilerine karşı daha sadık olmaları şaşırtıcı değildir. Ksenophon Kyrou Paideia'da hadım edilmiş hayvanlardan örnek vererek (atlar, boğalar ve köpekler) onları her ne kadar daha az kendinden emin-daha az saldırgan olarak değerlendirse de bu kişilerin görevini iyi yerine getiren ve savaşlarda çelik (silah) kullanabilen insanlar olduğunu vurgulamaktadır (Xenophon. Cyr. VII. 5. 59-65; Gera, 1993: 288). Ksenophon, öncesinde de benzer nedenlerle II. Kyros'un özel hizmetçileri ile kapı görevlilerini güvenilir ve sadık olduğunu düşündüğü hadımlar arasından seçtiğini belirtmektedir (Xenophon. Cyr. VII. 5. 65). Fakat Ksenophon'un bu konuda verdiği bilgiler oldukça çelişkilidir. Burada mevcut hadımlar arasından seçtiği korumalardan (kapı görevlileri) söz ederken hemen sonrasında kapı görevlisi hadımların kötü niyetli kişilere karşı duramamaları endişesiyle, sarayın Pers ülkesinden getirtilecek on bin muhafız tarafından korunmasına karar verdiğini açıklamaktadır. Hadımların harem içindeki koruma görevini (kap1 görevlileri olarak) üstlenmeleri mümkün görünse de sarayın asıl güvenliğinin "Ölümsüzler Birliği"' olarak da tanımlanan on bin kişilik seçkin bir birlik tarafından sağlanması daha gerçekçidir.

Konuyla ilgili olarak, Ktesias'ın vermiş olduğu bir başka detay da hadımların krala oldukça yakın saray mensupları olduğunu göstermektedir. Ktesias'a göre, II. Kyros'un ölümü üzerine 
oğlu II. Kambyses babasının cenazesini Bagapates adında bir hadım gözetiminde Persepolis'e göndermiş ve babasının vasiyetine uygun bir cenaze töreni düzenlenmesini emretmiştir (FGrH 688 F 13; Briant, 2002: 95; Dandamaev, 1989: 68). Görünüşe göre, hadımlar ölen bir kralın cesedini güvenli bir şekilde mezarına taşımakla da görevlendirilmişlerdir (Pirngruber, 2011: 281). Kralların yaşarken yakınında bulunan hadımlara ölen bir kralının cenazesinin teslim ediliyor olması, onlara duyulan güveni ve üstlendikleri kritik görevi ortaya koymaktadır.

Ktesias'ın eserinde (Persika) hadımlar daha çok olumsuz rollerde, özellikle de efendilerine karşı sıklıkla kurdukları komplo planlarıyla karşımıza çıkmaktadır (FgrH 688 F. 1, FgrH 688 F. 13, FgrH 688 F. 14, FgrH 688 F. 15). Buna karşılık, Herodotos hadımların genellikle koruma veya eşlik etme işlerinde görev aldığından bahseder. Hatta Pers hanedanından Teaspes oğlu Sataspes'in harem ağasının (hadım), Sataspes'in ölümü üzerine efendisinin servetini çalarak Samos'a kaçtı̆̆ına değinmektedir (Herodotos. IV. 43). Herodotos'un hadımlarla ilgili anlattığ1 en dramatik hikaye, I. Kserkses' in hadımlarının başı olan Hermotimos ile ilgilidir. Pedasoslu Hermotimos, savaş esiri olarak köle pazarına düşmüş ve Panionios adında bir köle tüccarı tarafından hadım edildikten sonra, Sardeis'teki köle pazarından Pers kralına armağan olarak gönderilmiştir. Zamanla I. Kserkses'in sarayındaki diğer hadımlar arasından sivrilerek kralın sevgisini kazanmış ve harem ağalarının başı olmuştur. I. Kserkses' in Hellas üzerine yapacağı sefer için hazırlandığı sırada, Atarneus'a bir görev için giden Hermotimos burada Panionios ile karşılaşmıştır. Panionios'a çok iyi davranarak karısı ve çocuklarıyla birlikte yanına davet eden Hermotimos, sonrasında Panionios'u dört oğlunu hadım etmeye mecbur edip, çocukları da babalarını hadım etmeye zorlayarak intikamını almıştır (Herodotos. VIII. 104-106).

Kyrou Paideia'da bahsi geçen Gadatas adındaki hadımın cesaret ve sadakatini yansıtan öykü de dikkat çekicidir. Assur Kralı'na (Yeni Babil) bağlı prenslerden biri olan Gadatas, kendisine siyasi rakip görmesi nedeniyle Assur Kralı tarafından hadım ettirilmiştir (Xenophon. Cyr. V. 2. 28). Bu sırada Pers kralı II. Kyros da bölge üzerine sefere çıkmıştır. Hadım edilmesini kabullenemeyen ve intikam almak isteyen Gadatas, II. Kyros'a giderek iş birliği yapmak istediğini bildirip kendi sorumluluğu altındaki kaleleri Pers kralına teslim etmiştir. Babil krallığının ele geçirilebilmesi için Perslere bölgedeki yiyecek-su kaynakları, yollar ve nehirlerin geçilebilecek noktaları gibi bilgileri Gadatas'ın sağladığı görülmektedir. Hatta Gadatas, Pers komutanlarından Gobryas ile birlikte Babil sarayını ele geçiren müfrezenin de başında yer almıştır (Xenophon. Cyr. VII. 5. 24-32; Briant, 2002: 271; Gera, 1993: 195). Görüldüğü üzere, Gadatas Babil seferi sırasında hem II. Kyros'a destek oluyor hem de Babil ülkesindeki Pers ordusuna rehberlik ediyordu. Pers kralı II. Kyros ile hadım Gadatas arasındaki yakınlaşmanın aslında bu ikilinin çıkarlarının çakışmasından kaynaklandığı anlaşılmaktadır (Gera, 1993: 259). II. Kyros Babil'e karşı savaşında her ne kadar Gadatas gibi hadımlardan destek bulsa da diğer yandan Babil kralına karşı yenilmiş bir hadımın kendisine yaklaşmasından da endişe duymuş olmalıdır. Bu nedenle sarayını koruyacak muhafızların Pers ülkesinden getirtilecek on bin mızraklı adamdan oluşmasını uygun bulmuştur (Xenophon. Cyr. VII. 5. 65-68).

\section{Çocuk Bakımı-Eğitimi}

Hadımların Pers sarayında üstlendikleri görevler arasında, çocuk bakımıyla ilgilendiklerine dair ipuçlarından birine Plutarkhos'un Alkibiades (Alcibiades) adlı eserinde rastlamaktayız. Plutarkhos, Pers sarayında bir çocuğun beslenmesiyle ilgilenen hemşire kadar, yüksek rütbeli hadımların da kral çocuklarının bakım hizmetinde bulunduğunu ve hadımların çocukların kol 
ve bacaklarını olabildiğince düzgün hale getirmekten büyük onur duyduklarını aktarır (Plutarkhos. Alc. 121d, 121e, 122a; Olmstead, 1948: 450; Briant, 2002: 226). Platon da Yasalar (Nomoi/Laws) adlı eserinde, benzer şekilde kadınlar ve hadımların Medlerin oğullarına verdiği eğitimden söz eder (Platon. Laws 694b-96a; Llewellyn-Jones, 2013: 187). Platon, burada Perslerin çöküşünü II. Kyros'un oğullarından II. Kambyses'le başlatarak, aslında bu durumun kadınlar ve hadımların elinde bozulan Med tarzı eğitim sisteminden kaynaklandığını belirtmektedir. Anlaşılan o ki, kadınlar ve hadımların eğitim sistemindeki varlığı Platon tarafından çöküş sürecini başlatan nedenlerden biri olarak görülmüştür.

Herodotos ise, I. Kserkses' in karısı Artemisia ve çocuklarını Ephesos'a gönderirken çocuklara bakmak üzere hadım Hermotimos'un da onların yanında bulunduğundan söz eder (Herodotos. VIII. 104). Hermotimos Pers sarayındaki hızlı yükselişiyle birlikte haremdeki çocuklara ders veren ayrıcalıklı kişilerden biri olmuştur (Hornblower, 2003: 37-57).

Görüldüğü üzere, hadımların Pers sarayında üstlendikleri önemli görevlerden biri de çocukların bakım ve eğitimleriyle ilgilenmekti. Hadım edilen erkekler hem görünüş hem de davranış açısından daha feminen (kadınsı) olmaları nedeniyle saraydaki kadınlarla birlikte bu görevi yürütmek için uygun bulunmuş olmalıdır. Fakat yukarıda da sözünü ettiğimiz üzere Platon, kadınlar ve hadımların eğitim sisteminde yer almasını, çöküşün başlangıcı olarak değerlendirerek olumsuz bir algı sunmuştur. Antik Hellen dünyasının kendilerinden olmayanlara bakışını değerlendiren Hall, saraydaki hadımlarla ilgili Hellen kaynaklarına yansıyan olumsuz bakış açısını, Asya'nın sistematik bir biçimde feminize edilmesiyle (dişileştirilmesi) özetlenebileceğini belirmektedir (1989: 157).

Hadım edilen erkeklerde, hormon dengesinin farklılaşmasıyla birlikte görülen en önemli fiziksel değişimlerden biri sakal ve bıyıkların seyrekleşmesi veya yok olmasıdır. Persepolis'deki Dareios'un sarayında bir ellerinde havlu (?), diğer ellerinde şişe (parfüm) taşıyan küpeli ve sakalsız tasvirler (Şekil 1-2) olasılıkla hadımlara ait olmalıdır (Schmidt, 1953: 165). İran'daki Pers sanatına ait örneklere baktığımızda, kadınlara ait betimlemelere neredeyse hiç rastlanmaması, kabartmalardaki sakal-bıyıksız figürlerin hadımlara ait olma olasılığını güçlendirmektedir. Persepolis'te ele geçmiş, günümüzde Tahran Müzesi'nde sergilenen, Lapis Lazuli' den (Lacivert Taşı) yapılmış heykel başının kadın, genç erkek veya hadım betimlemesi olup olmadığına dair tartışmalar sürse de İran sanatında alışık olduğumuz saçlı-sakallı erkek tipinin dışında bir profil sunması ve kadın fügürlerinin yok denecek kadar az olması gibi nedenlerle, eserin bir hadım betimlemesi olduğunu düşünmek mümkündür (Şekil 3).

\section{Değerlendirme ve Sonuç}

Hadımların Pers saray yaşamındaki rolünü değerlendirmeye çalışırken, içeriği itibariyle oldukça karışık ve bir o kadar da çelişkili ifadelerin bulunduğu antik kaynaklara bağlı olmak, karşılaştı̆̆ımız önemli zorluklarından biridir. Bu yüzden söyleyeceğimiz her söz Herodotos, Ksenophon, Diodoros, Ktesias, Plutarkhos, Platon vb. kaynakların verdiği bilgiler veya ipuçlarından öteye gidememektedir. Perslerin kendi kültürlerine ait geriye sinırlı belgeler bırakmış olması da bu konuda analojik bir değerlendirme yapmayı zorlaştırmaktadır. Tüm bu zorluklara rağmen hadımların Pers sarayının merkezinde yer aldığını söylemek mümkündür.

Hadımlar üstlendikleri görevler gereği kral ve saray yaşamına son derece yakın kişilerdir. Pers krallarının hem özel yaşamının hem de soylarının emanet edildiği kişiler olması bu durumun en önemli sebeplerinden biridir. Büyük kral veya saray yaşamına bu kadar yakın bulunan kişiler, elbette saray yaşamında birtakım sorunlara da neden olmuş olmalıdır. Bu yüzden 
hadımların saray yaşamında üstlendiği olumlu rollerin yanı sıra olumsuz örneklerle anılması da oldukça olağandır. Hadımlar, Pers İmparatorluğu'nun güçlü olduğu dönemde saray yaşamının sadık bir mensubu olarak tanımlanmakla birlikte, çöküş sürecinde tehlikeli (karmaşaya sebep olan) zayıf karakterlere dönüşmektedir.

Aslında genel olarak Misır, Mezopotamya ve Anadolu ekseninde şekillenen ancak başta da belirttiğimiz üzere en erken belgelerine Çin kaynaklarında ulaştı̆̆ımız hadım kavramı birçok toplumda karşımıza çıkar. Persler başlangıçta hadım etme eylemini bir cezalandırma yöntemi olarak uygulamış olsalar da hadımların saray yaşamının önemli unsurlarından biri haline gelmesiyle bu negatif tutumun, zamanla yerini hadımlara karşı duyulan güven duygusuna bıraktığı gözlenmektedir. Hadımların efendilerine gösterdikleri sadık yaklaşım, bu güveni daha da artırmış olmalıdır.

Herodotos, hadım edilme olayını ne kadar iğrenç bir duygu olarak aktarırsa aktarsın aynı zamanda hadımların saray yaşamındaki etkinliğine de dikkat çekmektedir. Benzer şekilde Ksenophon da çelişkili örnekler sunmasına rağmen hadımların saray yaşamındaki güvenilirliğini sıklıkla vurgular. Öte yandan, Ktesias ve Platon'un eserlerinde hadımlar daha olumsuz rollerde karşımıza çıkar. Ancak, ister olumlu ister olumsuz örneklerle anılsın hadımlar Pers saray yaşamının odağında yer almaktadır

Başta özel yaşam olmak üzere, günlük yaşamda ihtiyaç duydukları diğer yakın hizmetlerin karşılanması, kralların zehirlenme ihtimaline karşı içeceklerinin kontrolü, bunun yanı sıra ölmüş bir Pers kralının cesedinin emanet edilmesi gibi görevlerde hadımların saray içinde veya dişında kritik hizmetler üstlendiklerini görüyoruz. Ayrıca, saraydaki çocukların bakım ve eğitimi gibi, Pers kral ve soylularını doğrudan ilgilendiren konularda hadımlara görev verilmiş olması, daha önce de belirttiğimiz üzere hadımların saray yaşamında edindiği güven duygusuyla doğrudan ilişkilidir. 


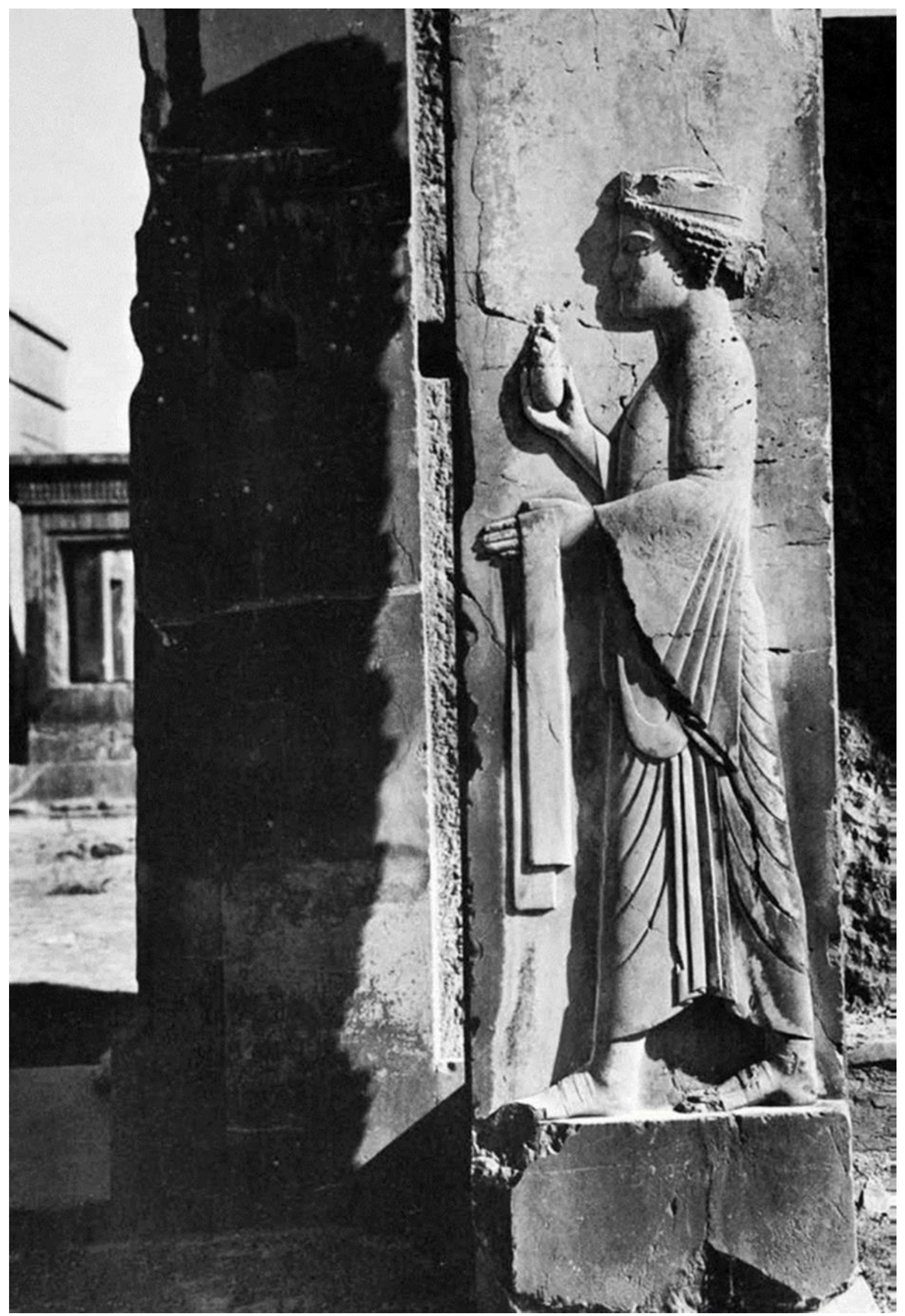

Şekil 1. Havlu ve parfüm şisesi taşıyan hadım (?) kabartması (Schmidt 1953, Levha 149). 


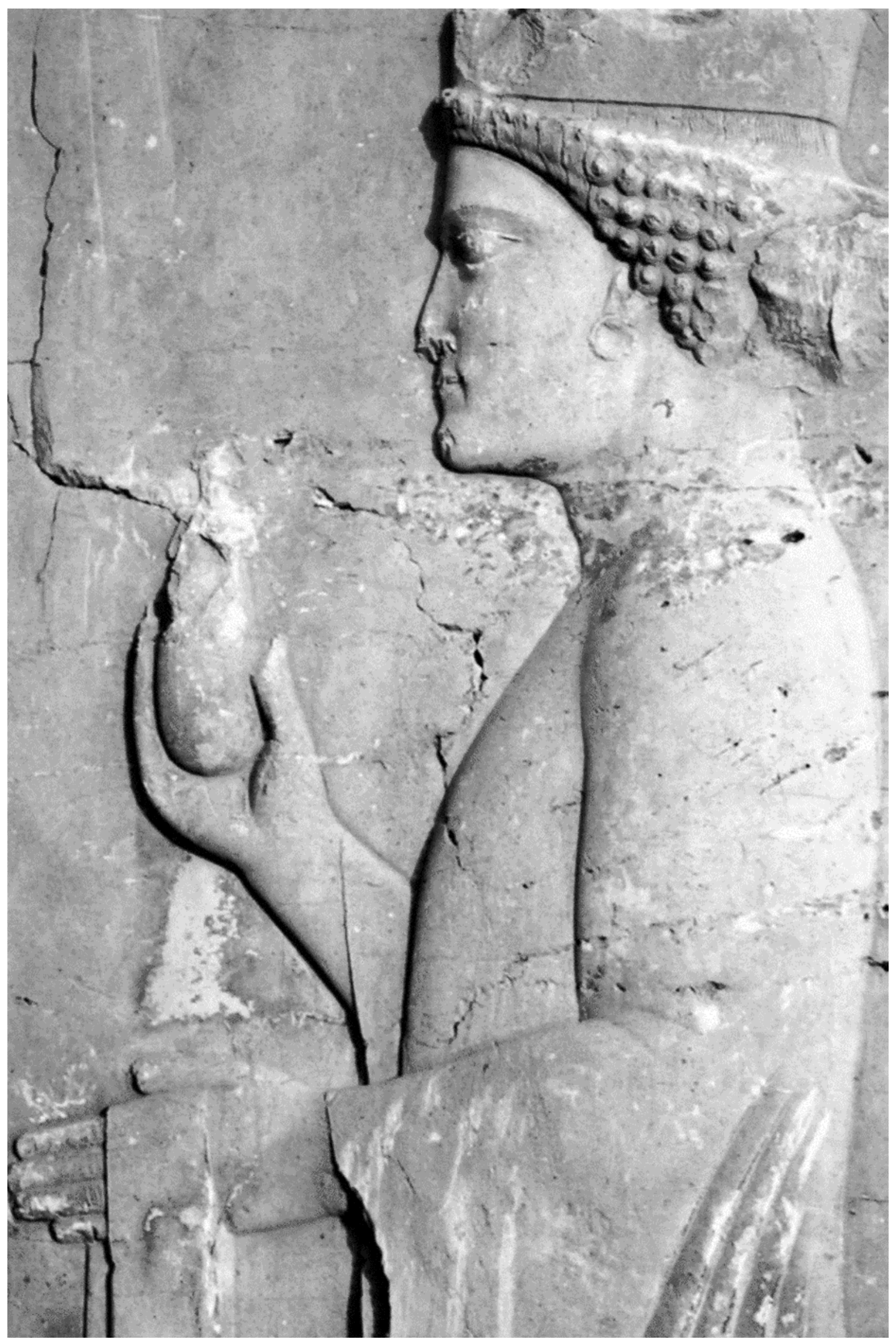

Şekil 2. Aynı kabartmadan detaylı görünüm (Llewellyn-Jones 2013, F 9). 


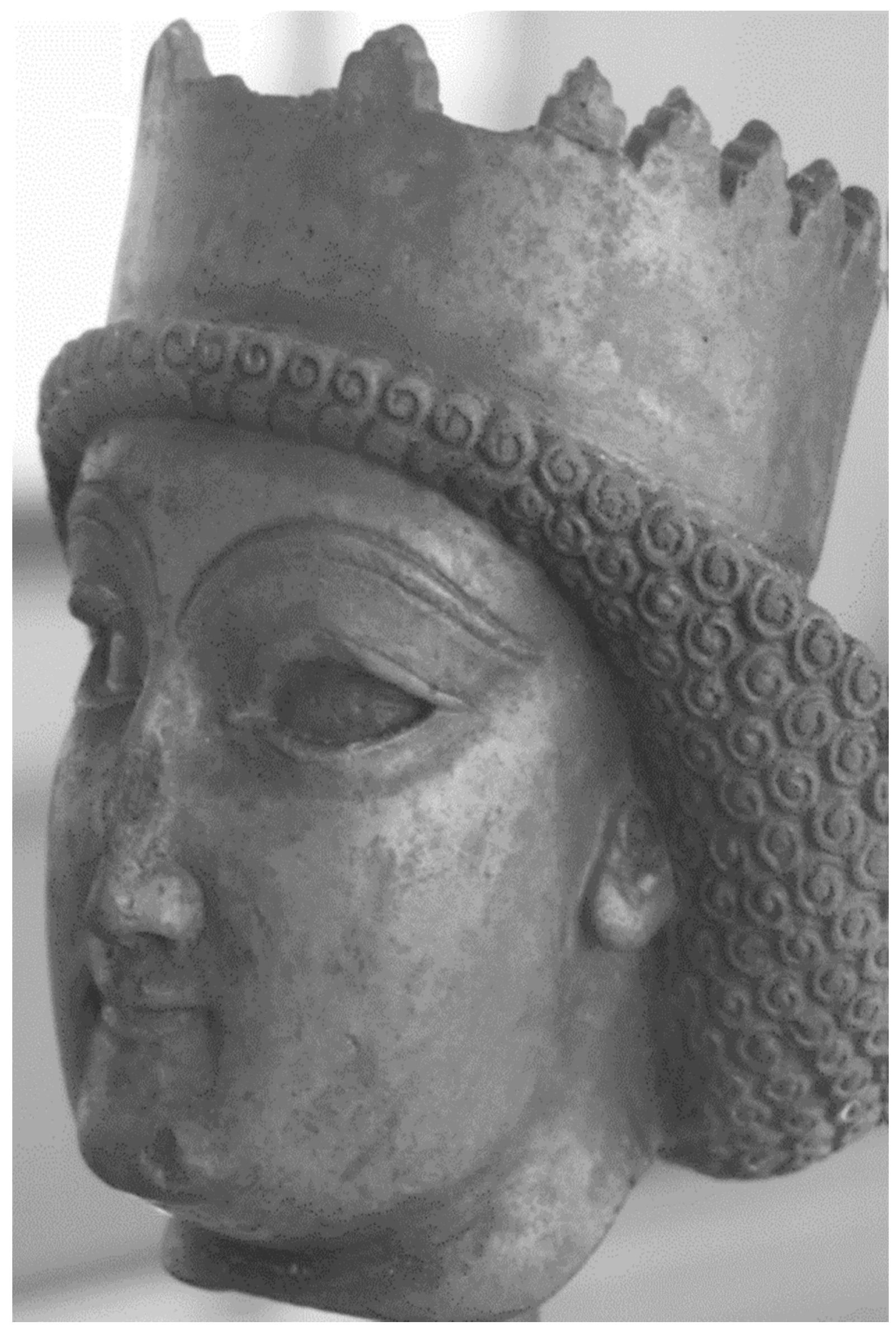

Şekil 3. Lapis Lazuli'den yapılmış heykel başı (Llewellyn-Jones 2013, F 4). 


\section{Kaynakça}

\section{Antik Kaynaklar}

Diodorus Siculus, (1989). Bibliotheca Historica (Çev: C. H. Old father). Harvard University Press.

FGrH, (1923) F. Jacoby, Die Fragmente der griechischen Historiker Kommentar Leiden.

Herodotos, (1920). Historiai, (Çev: A. D. Godley), Cambridge, The Loeb Classical Library.

Plato Laws., (1961). Laws, Vol. IX, Books I-VI, (Çev: R. G. Bury), London,The Loeb Classical Library.

Plutarkhos Alc., (1927). Charmides, Alcibiades I \& II, Hipparchus, The Lovers, Theages, Minos, Epinomis, (Çev: W.R.M. Lamb), London, The Loeb Classical Library.

Xenophon Cyr., (1960) Kyrou Paideia (Çev: W. Miller), London, The Loeb Classical Library.

\section{Modern Kaynaklar}

Azoulay, V. (2000). “Xénophon, la Cyropédie et les eunuques: généalogie d'un monstre?" Revue française d'histoire des idées politiques, 11, s. 3-26.

Briant, P. (1996). Histoire de l'empire perse de Cyrus à Alexandre, Paris.

Briant, P. (2002). From Cyrus to Alexander: A History of the Persian Empire (Çev: P. Daniels), Eisenbrauns, Paris.

Brosius, M. (1996). Women in Ancient Persia (559-331 BC). Oxford.

Dandamaev, M. A. (1989). Political History of the Achaemenid Empire, Leiden.

Gera, D. L. (1993). Xenophon's Cyropaedia Style, Genre, and Literary Technique, Clarendon Press, Oxford.

Gera, D. L. (1997). Warrior Women: The AnonymousTractatus de Mulieribus, Leiden.

Hall, E. (1989). Inventing the Barbarian: Greek self-definition through tragedy, Oxford.

Hornblover, S. (2003). "Panionios of Chios and Hermotimos of Pedasa (Hdt. 8.104106)" Herodotus and His World. Essays from a Conference in Memory of George Forrest, Ed. P. Derow and R. Parker,Oxford, s. 37-57.

Kuhrt, A. (2007). The Persian Empire: A Corpus of Sources from the Achaemenid Period, Routledge, London and New York.

Liddell \& Scot, H. G.\&R. (1996). A Greek-English Lexicon, Clerandon Press, Oxford.

Llewellyn-Jones, L. (2002). "Eunuchs and the royal harem in Achaemenid Persia",Eunuchs in Antiquity and Beyond, Ed. S. Tougher, The Classical Press of Wales, London, s. 19-50.

Llewellyn-Jones, L. (2013). King and Court in Ancient Persia 559 to 331 BCE (Debates and Documents in Ancient History), Edinburgh University Press.

Olmstead, A. T. (1948). History of the Persian Empire, Chicago.

Pirngruber, R. (2011). "Eunuchen am Königshof Ktesias und die altorientalische Evidenz", Ktesias' Welt Ctesias' World, Ed. R. Rollinger, J. Wiesehöfer, G. B. Lanfranchi, Wiesbaden: Harrassowitz Verlag, s. 279-312. 
Ringrose, K. (2003). The Perfect Servant: Eunuchs and the Social Construction of Genderin Byzantium, University of Chicago Press, Chicago, IL and London.

Sarp, N. (2013). "Kısırlaştırma (Sterilizasyon)", Kuzey Kıbrıs Türk Cumhuriyeti Lefke Avrupa Üniversitesi, IV. Sağlık Hakkı ve Sağlık Hukuku Sempozyumu, Ed. N. Sarp ve C. Doğan 7-8 Mayıs 2012, Ankara: Adalet Yayınları, s. 51-61.

Schmidt, E. F. (1953). Persepolis I, Chicago.

Scholz, P. (2001). Eunuchs and Castrati: A Cultural History, (Çev:J. Broadwin \& S. Frisch),Markus Wiener Publishers, Princeton.

Taylor, G. (2000). Castration: An Abbreviated History of Western Manhood, Routledge, New York and London.

Tougher, S. (2008). , The Eunuch in Byzantine History and Society, Routledge, New York and London.

Waters, M. (2017). Ctesias' Persica and Its Near Eastern Context, The University of Wisconsin Press, Madison, Wisconsin.

Wiesehöfer, J. (2003). J. Wiesehöfer, Antik Pers Tarihi, (Çev: M.A. İnci), İstanbul. 